\title{
Occurrence of ticks in dogs in a hospital population in the state of Espírito Santo, Brazil ${ }^{1}$
}

\author{
Fernanda T. Vieira ${ }^{2}$, Marcelo B. Labruna ${ }^{4}$ Anna Claudia M.S. Barbosa ${ }^{3}$, \\ Anderson R. Aguiar ${ }^{3}$, Igor C.L. Acosta ${ }^{4}$, Thiago F. Martins ${ }^{4}$, Reynaldo Dietze ${ }^{5}$ \\ and Fabio R. Braga ${ }^{3 *}$
}

\begin{abstract}
Vieira F.T., Labruna M.B., Barbosa A.C.M.S., Aguiar A.R., Acosta I.C.L., Martins T.F., Dietze R. \& Braga F.R. 2018. Occurrence of ticks in dogs in a hospital population in the state of Espírito Santo, Brazil. Pesquisa Veterinária Brasileira 38(3):519-521. Laboratório de Parasitologia Experimental e Controle Biológico, Universidade Vila Velha, Vila Velha, ES 29102-920, Brazil. E-mail: fabioribeirobraga@hotmail.com

Ticks, along with fleas, are considered the main ectoparasites affecting dogs in Brazil. The literature is rich in reports on the occurrence of ticks, which are vectors of diseases in both dogs and humans. The study of the epidemiology of these arthropods provides important data that can help control the infestation in residential areas where dogs are present. Thus, the study of their occurrence in urban areas and veterinary services is very important. The aim of the present study was to determine the occurrence of ticks in dogs in a veterinary hospital population in the state of Espírito Santo, Brazil. Over a one-year period (July 2012 to July 2013), 1483 dogs brought to veterinary services in south-eastern Brazil were examined. Among the dogs examined, $8.97 \%$ presented tick infestation, of which $100 \%$ were identified as Rhipicephalus sanguineus sensu lato. Given that this species of tick acts as a vector for diseases, it is important that the official health services monitor the occurrence of infestation in dogs and humans, in order to identify diseases transmitted by these ticks in this region.
\end{abstract}

INDEX TERMS: Ticks, dogs, Rhipicephalus sanguineus sensu lato, Espírito Santo, Brazil, parasitoses.

RESUMO.- [Ocorrência de carrapatos em cães de população hospitalar no Espírito Santo.] Os carrapatos, juntamente com as pulgas, são considerados, no Brasil, como os principais ectoparasitas do cão. A literatura é rica em relatos considerando a ocorrência de carrapatos, que são vetores de doenças para cães e humanos. 0 estudo da epidemiologia de artrópodes é um dado importante que pode ajudar a controlar a infestação em áreas domiciliadas com a presença de cães. Nesse sentido, o estudo de sua ocorrência em áreas urbanas e ou mesmo

\footnotetext{
${ }^{1}$ Received on November 17, 2016.

Accepted for publication on April 28, 2017.

${ }^{2}$ Laboratório de Patologia Animal, Universidade Vila Velha, Vila Velha, ES 29102-920, Brazil.

${ }^{3}$ Laboratório de Parasitologia Experimental e Controle Biológico, Universidade Vila Velha, Vila Velha, ES 29102-920, Brazil. Scholarship CNPq. *Corresponding author: fabioribeirobraga@hotmail.com

${ }^{4}$ Faculdade de Medicina Veterinária e Zootecnia, Departamento de Medicina Veterinária Preventiva e Saúde Animal, Universidade de São Paulo, São Paulo, SP 05508-010, Brazil.

${ }^{5}$ Centro Biomédico, Núcleo de Doenças Infecciosas, Universidade Federal do Espírito Santo, ES 29043-900, Brazil.
}

em serviços médicos veterinários é importante. 0 objetivo do presente estudo foi verificar a ocorrência de carrapatos em cães em uma população hospitalar do estado de Espírito Santo, Brasil. Durante um ano (julho de 2012 a julho de 2013), foram examinados 1483 cães atendidos em serviços hospitalares no sudeste do Brasil. Entre os cães examinados, 8,97\% apresentaram infestação de carrapatos, sendo $100 \%$ deles identificados como Rhipicephalus sanguineus sensu lato. Uma vez que se trata de uma espécie de carrapato que atua como vetor de doenças, é importante que os serviços oficiais de saúde mantenham um monitoramento da ocorrência de infestação tanto em cães como em humanos, a fim de identificar doenças transmitidas por esses carrapatos nesta região.

TERMOS DE INDEXAÇÃO: Carrapatos, cães, Rhipicephalus sanguineus sensu lato, Espírito Santo, parasitoses.

\section{INTRODUCTION}

In Brazil, the coexistence of dogs and humans can be evaluated using population estimates, which in 2009 , indicated the existence of 23,513,039 dogs (Dotti 2005, Otranto et al. 2013). This figure 
represents an average of one dog per eight inhabitants, based on IBGE data that indicated a human population in Brazil of $193,733,795$ in that same year (Brasil 2010). However, this close relationship between humans and dogs means that ticks are direct agents in the transmission of pathogens to both species, through the saliva.

Ticks are mites belonging to the Ixodidae order. They are widely distributed worldwide, including Brazil, acting as parasites in humans, domestic and wild animals, farm animals, and pets, as well as acting as vectors for disease agents to their hosts (Serra-freire \& Mello 2006). Larsson (1995) found that in the daily routine of the veterinary clinic for domestic carnivores, skin diseases accounted for about $30 \%$ of clinical care, regardless of the geographical location and socio-economic development of the country in question. In dogs, Rhipicephalus sanguineus sensu lato (s.l.) causes discomfort and anemia, and is a vector for various agents such as Ehrlichia canis, Babesia vogeli, Hepatozoon canis, Coxiella burnetii, and Anaplasma platys (Dantas-Torres 2008a, Almeida et al. 2012, Dantas-Torres et al. 2012). Babesiosis caused by Babesia vogeli, and Ehrlichiosis caused by Ehrlichia canis, are considered the most important diseases in dogs, and are both transmitted by $R$. sanguineus s.l. Meanwhile, Rickettsia conorii and Rickettsia rickettsii are the most important pathogens in humans transmitted by the same tick (Dantas-Torres et al. 2012).

Bellato et al. (2003) recorded, over a one-year period, in the city of Lages, Santa Catarina, a prevalence of $52.8 \%$ of dogs infected by ticks. Labruna et al. (2001) reported that the prevalence of ticks in dogs from a rural region in northern Paraná was $14.3 \%$, and the species most commonly found was $R$. sanguineus s.l. Oyafuso et al. (2002) reported that in northern Paraná, of the 71 tick samples collected, 4\% were identified as belonging to the genus Amblyomma, and $96 \%$ as $R$. sanguineus s.l. In a metropolitan area of Recife, Dantas Torres et al. (2004) found that $90 \%$ of stray dogs and $73.8 \%$ of pet dogs presented $R$. sanguineus s.l. Castro \& Rafael (2006) reported that in Manaus, $80 \%$ of the animals were affected by ectoparasites, of which $63 \%$ were $R$. sanguineus s.l. In fact, $R$. sanguineus s.l. is currently considered, along with fleas, to be the main ectoparasite affecting dogs throughout Brazil (Labruna 2004).

Within this context, the present study aimed to report the occurrence of ticks in dogs found by veterinary services in south-eastern Brazil, being this an educational tool and an update for veterinary and scientific medicine.

\section{MATERIALS AND METHODS}

Over a one-year period (July 2012 to July 2013, excluding the months of December, January and February) at the Veterinary Hospital of the University Vila Velha, Vila Velha, Espírito Santo, owners who brought their dogs to the clinic were approached, and after the owners had given their consent, the dogs were inspected for the presence of ticks. If ticks were present in the dog's fur, ectoparasite samples were collected, either manually or using tweezers, and stored in bottles containing 100\% alcohol. The ticks were identified using a stereoscopic microscope. The total number of dogs brought to the clinic, and the total number of dogs harbouring ticks, was counted. The prevalence was obtained by dividing the number of dogs with ticks by the number of dogs seen, and the result was multiplied by 100 to obtain the percentage. The Mean Abundance and Mean
Intensity of Infestation were also calculated, using the criteria suggested by Bush et al. (1997).

The ticks were collected from the dogs after gaining the approval of the animal ethics committee of Universidade Vila Velha (process number 215-2012). The samples were collected only after the owner of each animal had signed an informed consent form.

\section{RESULTS AND DISCUSSION}

From a total of 1483 dogs, 40.5\% (600) male and 59.5\% (883) female, of various breeds and ages (mean age 4.1 years) brought to the Veterinary Hospital of University Vila Velha during the study period, only $9.87 \%$ (133) presented ticks. A total of 665 tick specimens were collected. The mean intensity of infestation observed was 5, while the mean abundance of infestation was 0.45 . This result is relatively low, given that other studies have shown higher frequencies of dogs infested with ticks, Rhipicephalus sanguineus s.l. being the species most commonly found. In urban areas of Minas Gerais, Linardi \& Nagem (1973) found this tick species in $32.9 \%$ of 282 dogs. In Juiz de Fora (MG), a prevalence of 35\% was found in dogs kept as pets in homes (Soares et al. 2006). In the state of Espirito Santo, a study performed in the inner cities verified the presence of $R$. sanguineus s.l. in 10 dogs living in a rural area and 2 dogs living in an urban area (Spolidorio et al. 2010). In 2011, a study in the city of Pinheiros, north of the state of Espírito Santo, 27 ticks were collected from dogs belonging to rural properties, with 24 identified as $R$. sanguineus s.l. (Acosta 2011). In Porto Alegre, Ribeiro et al. (1997) found this species in $93.2 \%$ of the infected animals; however their findings differed from those of the present study due to the fact that they analyzed stray animals. Another study found a prevalence of 67.5\% among stray dogs in Goiania (Rodrigues et al. 2001). The fact that stray animals were analysed may explain the high frequency of tick infestations compared to the findings of the present study, which analyzed only domesticated animals, which are subjected to basic hygiene care, and live mostly in apartments, given that this a large urban center where this type of construction is prevalent. We also note that the lower prevalence observed in this study may be due to the easier accessibility to ectoparasiticides by the population, and also better access to information.

A higher number of ticks was observed on female host dogs (57.3\%, i.e. 381 individuals, with a confidence interval of $95 \%$ estimated at $53.5 \%, 61.1 \%$ ) in relation to the males (42.7\%, i.e. 284 individuals, with a confidence interval of $95 \%$ estimated at 38.9\%, 46.5\%). The highest incidence of dogs with parasites was observed in the month of March, with $41.93 \%$ (56), followed by May $(20.43 \% ; 27)$ and April $(13.97 \%, 18)$. However, no collections were made in December, January or February, as the Hospital where the research was conducted was closed for the holidays, therefore it was not possible to suggest data relating to seasonality.

A hundred percent of the ticks collected in this study were identified as $R$. sanguineus s.l. This result may be linked to the fact that most dogs attended by the Veterinary Hospital of the University Vila Velha are raised in urban environments, not having access to forests and areas where wild carnivores and other mammals live, which would facilitate the occurrence of R. sanguineus s.l. only (Labruna \& Pereira 2001). This result is in agreement with other studies that reported high frequency 
of this tick in urban areas (Linardi \& Nagem 1973, Yamamura \& Vidottto 1982, Ribeiro et al. 1997, Rodrigues et al. 2001, Oyafuso et al. 2002, Soares et al. 2006).

According to Dipeolu et al. (1982), in urban areas, the availability of habitats for the free-living stages of $R$. sanguineus s.l. is abundant, as this tick has a habit of penetrating small holes or cracks in cement or wood surfaces, carpets and rugs, which can easily be found inside and around houses. These characteristics may have contributed to the fact that only ticks of this species were found in this host population. Thus, prevention and control of this ectoparasite in dogs is important for public health, as the dog can spread infected ticks to the home environment, from pet shops as well as veterinary hospitals or kennels. Therefore it is important to raise awareness among the general public about the diseases that can be transmitted to humans and animals through tick bites. For this purpose, this study suggests an informative booklet.

Given that this is a species of tick that acts as a vector for diseases, it is important that the official health services continually monitor the occurrence of infestation in dogs and humans, in order to identify diseases transmitted by these ticks.

Acknowledgements.- The authors would like to thank CNPq, Capes, Fapes for providing financial support and a grant. The authors also thank Luanderson Mendes Queiroz and Thiago Senna for their contribution.

\section{REFERENCES}

Acosta I.C.L. 2011. Avaliação epidemiológica de doenças infecciosas em criações domésticas na área de entorno da Reserva Biológica do Córrego dos Veados, Linhares/ES. Trabalho de Conclusão do Curso de Medicina Veterinária, Centro Universitário Vila Velha, Vila Velha/ES, Brazil.

Almeida A.B.P.F., Paula D.A.J., Dahroug M.A.A., Freitas A.G., Silva J.N., Dutra A., Nakazato L. \& Sousa V.R.F. 2012. Ehrlichia canis e Anaplasma platys em carrapatos de cães de Cuiabá, Mato Grosso. Semina, Ciênc. Agrárias 33(3):1123-1126. http://dx.doi.org/10.5433/1679-0359.2012v33n3p1123.

Bellato V., Sartor A.A., Souza A.P. \& Ramos B. 2003. Ectoparasitos em caninos do município de Lages/SC, Brasil. Revta Bras. Parasitol. Vet. 12:95-98.

Brasil 2010. Resultados divulgados no diário oficial da união em 4.11.10. Instituto Brasileiro de Geografia e Estatística (IBGE). Disponible at <http:// www.ibge.gov.br/home/estatistica/populacao/censo2010/resultados_dou/ ES2010.pdf> Accessed on Sept. 13, 2011.

Bush A.O., Lafferty K.D., Lotz J.M. \& Shostak A.W. 1997. Parasitology meets ecology on its own terms: Margolis et al. revisited. J. Parasitol. 83(4):575583. http://dx.doi.org/10.2307/3284227. PMid:9267395.

Castro M.C.M. \& Rafael J.A. 2006. Ectoparasitos de cães e gatos da cidade de Manaus, Amazonas, Brasil. Acta Amazon. 36(4):535-538. http://dx.doi. org/10.1590/S0044-59672006000400015.

Dantas-Torres F. 2008a. The brown dog tick, Rhipicephalus sanguineus (Latreille,1806) (Acari: Ixodidae): from taxonomy to control. Vet. Parasitol. 152(3/4):173-185. http://dx.doi.org/10.1016/j.vetpar.2007.12.030. PMid:18280045.
Dantas-Torres F., Figueiredo L.A. \& Faustino M.A.G. 2004. Ectoparasitos de cães provenientes de alguns municípios da região metropolitan do Recife, Pernambuco, Brasil. Rev. Bras. Parasitol. Vet. 13:151-154.

Dantas-Torres F., Giannelli A. \& Otranto D. 2012. Starvation and overwinter do not affect the reproductive fitness of Rhipicephalus sanguineus. Vet. Parasitol. 185(2-4):260-264. http://dx.doi.org/10.1016/j.vetpar.2011.10.005. PMid:22075042.

Dipeolu O.O., Akinboade O.A. \& Ogunji F.O. 1982. Observations on the epidemiology of house infesting Rhipicephalus sanguineus in a household in Lagos, Nigeria. Bull. Anim. Health Prod. Afr. 30(1):29-30. PMid:7186809.

Dotti J. 2005. Terapia e Animais. Editora Noética, São Paulo. 294p.

Labruna M.B. \& Pereira M.C. 2001. Carrapato em cães no Brasil. Clín. Vet. 30:24-32.

Labruna M.B. 2004. Bioecologia de Rhipicephalus sanguineus. Revta Bras. Parasitol. Vet. 13:123-124

Labruna M.B., Souza S.L.P., Guimarães Jr J.S., Pacheco R.C., Pinter A. \& Gennari S.M. 2001. Prevalência de carrapatos em cães de áreas rurais da região norte do estado do Paraná. Arq. Bras. Med. Vet. Zootec. 53(5):553-556. http://dx.doi.org/10.1590/S0102-09352001000500007.

Larsson C.E. 1995. Dermatoparasitoses de cães e gatos: patogenia, diagnóstico diferencial e saúde pública. Revta Bras. Parasitol. Vet. 4:261-270.

Linardi P.M. \& Nagem R.L. 1973. Pulicídeos e outros ectoparasitos de cães de Belo Horizonte e municípios vizinhos. Revta Bras. Biol. 33(4):529-537. PMid:4804478.

Otranto D., Dantas-Torres F., Brianti E., Traversa D., Petrić D., Genchi C. \& Capelli G. 2013. Vector-borne helminths of dogs and humans in Europe. Parasit. Vectors 6(1):16. http://dx.doi.org/10.1186/1756-3305-6-16. PMid:23324440.

Oyafuso M.K., Dagnone A.S., Vidotto O. \& Morais H.S.A. 2002. Caracterização de carrapatos parasitas de cães em uma população hospitalar no norte do Paraná. Semina, Ciênc. Agrárias 23(1):71-74. http://dx.doi.org/10.5433/16790359.2002v23n1p71.

Ribeiro V.L.S., Weber M.A., Fetzer L.O. \& Vargas C.R.B. 1997. Espécies e prevalência das infestações por carrapatos em cães de rua da cidade de Porto Alegre, RS, Brasil. Ciência Rural 27(2):285-289. http://dx.doi. org/10.1590/S0103-84781997000200019.

Rodrigues A.F.S.F., Daemon E. \& D’Agosto M. 2001. Investigação sobre alguns ectoparasitas em cães de rua no município de Juiz de Fora, Minas Gerais. Revta Bras. Parasitol. Vet. 10:13-19.

Serra-Freire N.M. \& Mello R.P. 2006. Acari e Crustacea, p.31-72. In: SerraFreire N.M. \& Mello R.P. (Eds), Entomologia e Acarologia na Medicina Veterinária. L.F. Livros, Rio de Janeiro.

Soares A.O., Souza A.D., Feliciano E.A., Rodrigues A.F., D’Agosto M. \& Daemon E. 2006. Avaliação ectoparasitológica e hemoparasitológica em cães criados em apartamentos e casas com quintal na cidade de Juiz de Fora, MG. Revta Bras. Parasitol. Vet. 15(1):13-16. PMid:16646996.

Spolidorio M.G., Labruna M.B., Machado R.Z., Moraes-Filho J., Zago A.M., Donatele D.M., Pinheiro S.R., Silveira I., Caliari K.M. \& Yoshinari N.H. 2010 Survey for tick-borne zoonoses in State of Espírito Santo, south-eastern Brazil. Am. J. Trop. Med. Hyg. 83(1):201-206. http://dx.doi.org/10.4269/ ajtmh.2010.09-0595. PMid:20595502.

Yamamura M.H. \& Vidottto O. 1982. Prevalência de hemoparasitos em cães da região norte do Paraná. Anais Congresso Brasileiro de Medicina Veterinária, Balneário Camboriú, SC, p.156. (Resumo) 